\title{
Traumatic wound dehiscence after penetrating keratoplasty
}

\author{
Baki Kartal, M.D., ${ }^{1}$ Baran Kandemir, M.D., ${ }^{2}$ Turan Set, M.D., ${ }^{3}$ Süleyman Kuğu, M.D., ${ }^{2}$ \\ Sadullah Keleş, M.D., ${ }^{4}$ Erdinç Ceylan, M.D., ${ }^{1}$ Berkay Akmaz, M.D., ${ }^{2}$ \\ Aytekin Apil, M.D., ${ }^{5}$ Yusuf Özertürk, M.D. ${ }^{2}$
}

\begin{abstract}
${ }^{1}$ Department of Ophthalmolgy, Regional Training and Research Hospital, Erzurum
${ }^{2}$ Department of Ophthalmology, Dr. Lutfi Kirdar Kartal Training and Research Hospital, Istanbul

${ }^{3}$ Department of Family Medicine, Atatürk University Faculty of Medicine, Erzurum

${ }^{4}$ Department of Ophthalmology, Atatürk University Faculty of Medicine, Erzurum

${ }^{5}$ Department of Ophthalmolgy, Bakirköy Sadi Konuk Training and Research Hospital, Istanbul
\end{abstract}

\begin{abstract}
BACKGROUND: We aimed to evaluate the risk factors, clinical features and outcomes of surgery for traumatic wound dehiscence (TWD) following penetrating keratoplasty (PK).

METHODS: Twenty-six patients with TWD following PK were evaluated retrospectively in terms of factors related to the trauma, types of reconstructive surgery, final graft clarity, and visual acuity.

RESULTS: There were 26 patients with a mean age of $40.7 \pm 19.6$ years. In 12 (46.1\%) patients, the better eye was affected by the trauma. The most frequent type of trauma was blunt trauma by various objects (9). In all cases, the dehiscence was at the graft host junction. The mean extent of detachment was $135.4^{\circ} \pm 57.6^{\circ}$. Crystalline or intraocular lens damage was present in $42.3 \%$ of cases. Median follow-up time after the reconstructive surgery was 36 months. The graft remained clear in $13(50 \%)$ patients, whereas graft insufficiency/graft rejection developed in 13 (50\%) patients. Final visual acuity was over 20/200 in 13 (50\%) patients.
\end{abstract}

CONCLUSION: TWD may occur at any time after PK, most frequently within the first postoperative year. Low visual acuity in the other eye seems to be a major risk factor. In patients without major complications such as posterior segment damage, visual outcomes and graft survival can be favorable.

Key words: Graft survival; penetrating keratoplasty; traumatic wound dehiscence; visual prognosis.

\section{INTRODUCTION}

Although the eyes comprise only $0.27 \%$ of our total body surface and $4 \%$ of the face, they are the third most frequently affected organ by trauma, after the hands and feet. ${ }^{[]]}$Worldwide, there are currently 1.6 million blind and 19 million monocular individuals as a result of ocular trauma, which makes it one of the most significant causes of ocular morbidity. ${ }^{[2]}$

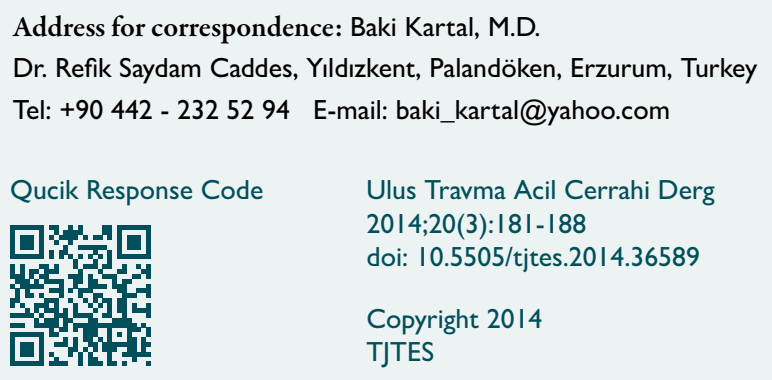

The incidence of traumatic globe rupture after penetrating keratoplasty (PK) and after planned extracapsular cataract extraction (ECCE) was reported as $0.6-5.8 \%^{[3-4]}$ and $0.4-$ $1.4 \%,{ }^{[5-6]}$ respectively. Therefore, PK is more prone to traumatic globe rupture than the other types of ocular surgery. The World Health Organization (WHO) reported that almost 120,000 PKs were performed worldwide in $2000,\left[{ }^{[7]}\right.$ and the donor supply increased $21 \%$ between 1990 and 2000 in the United States. ${ }^{[8,9]}$ Considering this increase in the number of PKs (which is currently the most common homologous organ transplantation), an increase in cases of traumatic wound dehiscence (TWD) is also expected. Despite the low incidence of TWD following PK, the potentially serious complications with poor outcomes make the growing number of such cases a concern.

\section{MATERIALS AND METHODS}

This study was performed by retrospectively reviewing the 
records of 26 patients who were diagnosed with and underwent reconstructive surgery to correct traumatic graft rupture in the Eye Clinic of Kartal Dr. Lütfi Kirdar Training and Research Hospital between 2003 and 2012. Patients' records were evaluated with respect to age, gender, indication of PK, suturing technique, time interval between PK and the trauma, type of trauma, presence of sutures, steroid usage at the time of trauma, accompanying anterior and posterior segment damage, wound specifications, type of reconstructive surgical procedures, and final visual acuity and graft clarity.
The Statistical Package for the Social Sciences (SPSS) 18.0 package program were used and statistical analyses were done by frequency tables, Mann-Whitney U, Kruskal-Wallis, chi-square, and Wilcoxon tests. A value of $p<0.05$ was accepted as statistically significant.

\section{RESULTS}

There were 14 (54\%) males and 12 (46\%) females, with a mean age of $40.7 \pm 19.6$ years (range, $4-71$ ). There was no sig-

Table I. General demographic and medical data

\begin{tabular}{|c|c|c|c|c|c|c|c|c|c|}
\hline \multirow{2}{*}{$\begin{array}{l}\text { Patient } \\
\text { No }\end{array}$} & \multirow[t]{2}{*}{ Age } & \multirow[t]{2}{*}{ Gender } & \multirow[t]{2}{*}{ Indication of PK } & \multicolumn{2}{|c|}{ Follow-up (month) } & \multicolumn{2}{|c|}{ Suture } & \multirow{2}{*}{$\begin{array}{c}\text { Steroid } \\
\text { usage } \\
\text { during } \\
\text { trauma }\end{array}$} & \multirow{2}{*}{$\begin{array}{c}\text { Pretraumatic } \\
\text { other risk } \\
\text { factors }\end{array}$} \\
\hline & & & & $\begin{array}{l}\text { Between } \\
\text { PK-trauma }\end{array}$ & $\begin{array}{l}\text { After } \\
\text { trauma }\end{array}$ & $\begin{array}{l}\text { Suturing } \\
\text { technique }\end{array}$ & $\begin{array}{l}\text { Presence } \\
\text { of sutures } \\
\text { during } \\
\text { trauma }\end{array}$ & & \\
\hline 1 & 56 & Female & Corneal Scar & 2 & 112 & IS & + & + & Glaucoma \\
\hline 2 & 28 & Female & Keratoconus & 0.6 & 105 & ICS & + & + & - \\
\hline 3 & II & Male & Leukoma Adherence & 2 & 93 & IS & + & + & - \\
\hline 4 & 23 & Male & Granular Dystrophy & 6 & 68 & IS & + & + & - \\
\hline 5 & 24 & Male & Corneal Scar & 12 & 58 & IS & + & + & - \\
\hline 6 & 45 & Male & Keratoconus & 9 & 52 & IS & + & + & $\begin{array}{c}\text { Low vision in } \\
\text { other eye }\end{array}$ \\
\hline 7 & 47 & Male & Macular Dystrophy & 3 & 40 & IS & + & + & - \\
\hline 8 & 15 & Male & Keratoconus & 1 & 22 & ICS & + & + & - \\
\hline 9 & 60 & Male & Fuchs & 6.5 & 24 & IS & + & + & Glaucoma \\
\hline 10 & 71 & Male & PBK & 56 & 31 & IS & Removed & Stopped & - \\
\hline 11 & 25 & Female & Corneal Scar & 59 & 26 & IS & Removed & Stopped & Glaucoma \\
\hline 12 & 37 & Female & PBK & 16 & 26 & IS & + & Stopped & Glaucoma \\
\hline 13 & 50 & Female & Corneal Scar & 18 & 25 & IS & Removed & Stopped & - \\
\hline 14 & 30 & Female & Keratoconus & 1 & 21 & IS & + & + & $\begin{array}{l}\text { Glaucoma } \\
\text { +Deafness }\end{array}$ \\
\hline 15 & 45 & Female & Herpetic Keratitis & 72 & 20 & IS & Removed & Stopped & $\begin{array}{l}\text { Glaucoma } \\
+ \text { Single Eye }\end{array}$ \\
\hline 16 & 30 & Male & Keratoconus & 1 & 19 & ICS & + & + & $\begin{array}{l}\text { Glaucoma } \\
\text { (AGV) }\end{array}$ \\
\hline 17 & 47 & Female & Corneal Scar & 7 & 12 & IS & + & + & - \\
\hline 18 & 66 & Female & PBK & 1 & 12 & IS & + & + & - \\
\hline 19 & 48 & Male & Corneal Scar & 30 & 6 & ICS & Removed & Stopped & Single Eye \\
\hline 20 & 44 & Male & Corneal Scar & 44 & 43 & IS & Removed & Stopped & - \\
\hline 21 & 8 & Male & Graft Rejection & 2 & 117 & IS & + & + & Single Eye \\
\hline 22 & 4 & Female & Corneal Scar & 18 & 65 & IS & Removed & Stopped & Single Eye \\
\hline 23 & 61 & Male & Leukoma Adherence & 30 & 84 & IS & Removed & Stopped & Single Eye \\
\hline 24 & 49 & Female & Graft Rejection & 4 & 64 & IS & + & + & Single Eye \\
\hline 25 & 71 & Male & Leukoma Adherence & 35 & 27 & IS & Removed & Stopped & Single Eye \\
\hline 26 & 64 & Female & Corneal Scar & 26 & 16 & IS & Removed & Stopped & - \\
\hline
\end{tabular}

AGV: Ahmed glaucoma valve implant present; ICS: Interrupted combined with continuous sutures; IS: Interrupted sutures; PBK: Pseudophakic bullous keratopathy. 
nificant difference in the average age by gender $(Z=-0.386$, $\mathrm{p}=0.699$ ). Among the 1,625 PKs performed during the study period, the incidence of TWD was $1.6 \%$. The most frequent primary PK indication was corneal scar (8). In 30.8\% (8/26) of these cases, PK was combined with cataract extraction and intraocular lens (IOL) implantation; 69.2\% (18/26) underwent PK alone. Twenty-two (84.6\%) patients had been operated with 16 single sutures. The most frequent risk factor was low vision in the other eye (8), and the better eyes were affected by the trauma in $12(46.1 \%)$ cases. Sutures were present in $16(61.6 \%)$ patients, and $15(57.7 \%)$ patients were using steroids at the time of the trauma (Table I). Visual acuity was $0.26 \pm 0.21(5 \mathrm{mps}-20 / 25)$ in the traumatized eye and
$0.47 \pm 0.40(P[-]-20 / 20)$ in the other eye prior to trauma.

The median time interval between the PK and trauma was 8.0 months (range, 0.6-72 months). All of the traumas were blunt and found to be caused by various objects (9), by falls (6), and by hand (6) or finger slap (5). The average age of the fall-related injuries was found to be significantly higher $\left(\chi^{2}=12.540\right.$; $p=0.006$ ), but there was no significant relationship between etiology of the trauma and gender $\left(\chi^{2}=0.829 ; p=0.843\right)$.

The median time between the trauma and reconstructive surgery was 6 hours (range, $1-120$ hours) in 21 cases, and the time was not recorded in the remaining 5 . No statistically

Table 2. Data about dehiscence, final graft status and vision

\begin{tabular}{|c|c|c|c|c|c|c|}
\hline $\begin{array}{l}\text { Patient } \\
\text { No }\end{array}$ & $\begin{array}{l}\text { Quadrant of } \\
\text { dehiscence }\end{array}$ & $\begin{array}{l}\text { Extent of } \\
\text { dehiscence }\end{array}$ & $\begin{array}{l}\text { Final graft } \\
\text { status }\end{array}$ & $\begin{array}{l}\text { Pretraumatic } \\
\text { visual acuity }\end{array}$ & $\begin{array}{l}\text { Final visual } \\
\text { acuity }\end{array}$ & $\begin{array}{l}\text { Final low visual } \\
\text { acuity reasons }\end{array}$ \\
\hline $\mathrm{I}$ & Superior & 120 & Clear & ImFC & $2 \mathrm{mFC}$ & Pretraumatic PDRP \\
\hline 2 & Superior & 45 & Clear & 0.1 & 1.0 & - \\
\hline 3 & Nasal & 180 & Clear & $2 \mathrm{mFC}$ & $2 m F C$ & Amblyopia/Exotropia \\
\hline 4 & Superior & 90 & Clear & 0.7 & 0.7 & - \\
\hline 5 & Except Nasal & 270 & Insufficiency & 0.4 & HM & Graft Insufficiency \\
\hline 6 & Inferior & 120 & Insufficiency & 0.3 & 0.15 & Graft Insufficiency \\
\hline 7 & Inferior & 120 & Clear & 0.2 & 0.6 & Macular Pucker \\
\hline 8 & Temporal & 30 & Clear & 0.5 & 0.5 & - \\
\hline 9 & Inferior & 180 & Clear & 0.2 & $\mathrm{HM}$ & $\begin{array}{l}\text { Epithelial } \\
\text { Ingrowth+PVR }\end{array}$ \\
\hline 10 & Superior & 180 & Insufficiency & 0.15 & HM & $\begin{array}{l}\text { Graft } \\
\text { Insufficiency+Secondary } \\
\text { Glaucoma }\end{array}$ \\
\hline 11 & Superior & 180 & Rejected & $50 \mathrm{cmFC}$ & $50 \mathrm{cmFC}$ & Pretraumatic Graft Rejection \\
\hline 12 & Superior & 120 & Clear & 0.4 & 0.7 & - \\
\hline 13 & Inferior & 90 & Clear & 0.4 & $\mathrm{P}(+)$ & Suprachoroidal Hemorrhage \\
\hline 14 & Nasal & 45 & Rejected & 0.15 & 0.15 & - \\
\hline 15 & Superior & 180 & Insufficiency & 0.2 & $10 \mathrm{cmFC}$ & Graft Rejection \\
\hline 16 & Nasal & 140 & Clear & 0.4 & 0.4 & - \\
\hline 17 & Temporal & 60 & Rejected & 0.8 & 0.2 & Graft Rejection \\
\hline 18 & Nasal & 180 & Insufficiency & $2 \mathrm{mFC}$ & $10 \mathrm{cmFC}$ & $\begin{array}{l}\text { Graft } \\
\text { Insufficiency+Fibrous Ingrowth }\end{array}$ \\
\hline 19 & Inferior & 180 & Clear & 0.05 & $30 \mathrm{cmFC}$ & Geographic Atrophy \\
\hline 20 & Inferior & 180 & Rejected & 0.5 & 0.1 & Graft Rejection \\
\hline 21 & Inferior & 150 & Rejected & I mFC & $\mathrm{P}(+)$ & Graft Rejection \\
\hline 22 & Nasal & 90 & Insufficiency & 0.2 & HM & Graft Insufficiency \\
\hline 23 & Inferior & 180 & Clear & 0.4 & 0.15 & Retinal Vein Branch Occlusion \\
\hline 24 & Inferior & 200 & Rejected & 0.05 & $\mathrm{P}(+)$ & Graft Rejection \\
\hline 25 & Temporal & 120 & Clear & 0.3 & 0.1 & Geographic Atrophy \\
\hline 26 & Inferior & 90 & Clear & 0.4 & 0.5 & - \\
\hline
\end{tabular}

FC: Finger count; HM: Hand motion; PDRP: Proliferative diabetic retinopathy; PVR: Proliferative vitreoretinopathy. 
significant relationship was found between the time elapsed from trauma to reconstructive surgery and the final graft clarity ( $p>0.05)$ (Table 2). Each dehiscence was on the host-graft junction and was observed to be between $30^{\circ}$ and $270^{\circ}$ (mean, 135.38 $\left.\pm 57.61^{\circ}\right)($ Table 2). The degree of the host-graft dehiscence was not found to be statistically related to primary surgical indication, pretraumatic risk factors, suturing techniques, presence of the sutures, steroid use, etiology of the trauma, place of the dehiscence, or final graft status $(p>0.05)$ (Table $3)$. The most frequent site of dehiscence was in the inferior quadrant (10 patients). There was no significant relationship between the affected quadrant and the etiology of the trauma $\left(\chi^{2}=9.908 ; p=0.820\right)$ or degree of the graft dehiscence $\left(\chi^{2}=9.054 ; p=0.06\right)$. The ratio of patients with crystalline lens/ IOL damage was $42.3 \%$, and traumatic damage to these structures was found to be significantly related to final graft clarity $(p<0.05)$, but not related to the degree of the host-graft dehiscence $(p>0.05)$ (Table 3). Eight of the corneas (30.8\%) were clear, and the remaining 18 (69.2\%) were affected in varying degrees from mild corneal edema to totally opaque cornea at presentation after the trauma. Posttraumatic graft edema was not related to crystalline lens/lOL damage $\left(\chi^{2}=1.418\right.$; $p=0.234)$, degree of dehiscence $(Z=-0.459 ; p=0.646)$ or final graft status $\left(\chi^{2}=0.680 ; p=0.409\right)$. Other common anterior

Table 3. Factors associated with degree of the host-graft dehiscence and final graft status

$\begin{array}{ll}\text { Degree of the host-graft dehiscence } & \\ \text { Primary surgical indication* } & \chi^{2}=8.156 \mathrm{p}=0.319 \\ \text { Pretraumatic risk factors* } & \chi^{2}=2.65 \mathrm{I} \mathrm{p}=0.449 \\ \text { Suturing techniques }{ }^{\pi} & \mathrm{Z}=-0.656 \mathrm{p}=0.512 \\ \text { Presence of sutures }{ }^{\pi} & \mathrm{Z}=-\mathrm{I} .189 \mathrm{p}=0.234 \\ \text { Steroid use } & \mathrm{Z}=-0.931 \mathrm{p}=0.352 \\ \text { Etiology of the trauma* } & \chi^{2}=1.502 \mathrm{p}=0.682 \\ \text { Place of the dehiscence* } & \chi^{2}=9.054 \mathrm{p}=0.060 \\ \text { Final graft status* } & \chi^{2}=1.141 \mathrm{p}=0.565 \\ \text { Crystalline lens/IOL damage } & \mathrm{Z}=-\mathrm{I} .170 \mathrm{p}=0.116\end{array}$

Final graft status

$\begin{array}{ll}\text { Age* }^{*} & \chi^{2}=1.099 p=0.577 \\ \text { Gender }^{\epsilon} & \chi^{2}=1.666 p=0.435 \\ \text { Primary surgical indication }^{\epsilon} & \chi^{2}=9.547 p=0.216 \\ \text { Median time between PK and trauma } & Z=-0.668 p=0.504 \\ \text { Degree of dehiscence } & Z=-0.657 p=0.511 \\ \text { Affected quadrant } & \chi^{2}=2.076 p=0.722 \\ \text { Etiology of the trauma } & \chi^{2}=1.867 p=0.631 \\ \text { The median time between trauma } & Z=-0.179 p=0.858 \\ \text { and reconstructive surgery } & \\ \text { Reconstructive surgery type } & \chi^{2}=1.385 p=0.239 \\ \text { Crystalline lens/IOL damage } & \chi^{2}=7.369 p=0.025\end{array}$

*: Kruskal-Wallis test; ๆ: Mann-Whitney $U$ test; $€$ : Chi-square test. segment complications were vitreous (10) and iris prolapse (7). Posterior segment damage was noted as suprachoroidal hemorrhage (I), macular pucker (I), or retinal detachment with proliferative vitreoretinopathy (PVR) (I), and all of these patients had crystalline lens/IOL damage (Table 4).

Reconstructive surgical procedures were done under local anesthesia (retrobulbar and periocular) in 20 (76.9\%) patients and under general anesthesia in the remaining $6(23.1 \%)$ patients. Primary suture (PS) alone was employed in 13 patients, and PS combined with other interventions was performed in the remaining cases (Table 4).

Median follow-up time was 36 months (range, 6-I I7 months) after the reconstructive surgery. The rates of clear graft and graft insufficiency/graft rejection were I 3 (50\%) and I 3 (50\%), respectively. There was no significant relationship between the final graft status and age, gender, primary surgical indication, median time interval between PK and trauma, degree of dehiscence, affected quadrant, etiology of the trauma, or reconstructive surgery type $(p>0.05)$ (Table 3$)$. Visual acuity was $0.05 \pm 0.1$ (hand motions - 20/40) after the trauma, and it was $0.20 \pm 0.28(P(+)-20 / 20)$ at the final follow-up. There was no significant difference between pre-traumatic and final visual acuity $(Z=-1.736 ; p=0.083)$, but a statistically significant difference was found between posttraumatic and final visual acuity $(Z=-3.081 ; p=0.002)$. Visual acuity was decreased in 14 $(53.8 \%)$ cases, remained the same in $7(26.9 \%)$ cases, and increased in 5 (19.2\%) cases. At the final follow-up, visual acuity was better than 20/200 in $13(50 \%)$ eyes (Table 2). Epithelial ingrowth (I), fibrous ingrowth (I) and secondary glaucoma (I) were noted as anterior segment complications in addition to posterior segment-related complications (Table 2).

\section{DISCUSSION}

Any trauma to the globe with proper mechanism and sufficient force would cause rupture of the globe at the weakest region. ${ }^{[4]}$ In virgin eyes, these regions are insertions of extraocular muscles or the corneoscleral limbus, ${ }^{[10]}$ whereas in wounded eyes with previous surgery or penetrating trau$\mathrm{ma}$, the rupture site will be the previous corneal scar. ${ }^{[1]} \mathrm{PK}$ comprises a full thickness $360^{\circ}$ surgical wound and creates permanent weakness in the eyeball throughout patients' lives. ${ }^{[12-14]}$ Calkins et al. ${ }^{[15]}$ demonstrated that in human corneas, weakness at the host-graft junction persists even a year after PK, despite the appearance of having healed.

Mental retardation, low vision in both eyes, deafness, and alcohol consumption are accepted risk factors for traumatic rupture following PK. ${ }^{[3,11,16,17]}$ Older age, obesity, use of nonirritating nylon sutures, improper suturing, early suture removal, and glaucoma have been reported to delay corneal wound healing. ${ }^{[18]}$ In our study group, at least one of these risk factors was present in $53.8 \%$ (14) of cases: low vision in the other eye (8), glaucoma (7) and deafness (I). Addition- 
Table 4. Surgical procedures, traumatic crystalline lens/IOL and posterior segment damage

\begin{tabular}{|c|c|c|c|c|c|}
\hline \multirow{2}{*}{$\begin{array}{l}\text { Patient } \\
\text { No }\end{array}$} & \multirow{2}{*}{$\begin{array}{l}\text { Surgical } \\
\text { procedure }\end{array}$} & \multirow[t]{2}{*}{ Secondary surgery } & \multicolumn{2}{|c|}{ Status of lens } & \multirow{2}{*}{$\begin{array}{l}\text { Posterior segment } \\
\text { damage }\end{array}$} \\
\hline & & & Pre-trauma & Post-trauma & \\
\hline \multirow[t]{2}{*}{ I } & PS & - & Pseudophakic & Pseudophakic & - \\
\hline & & & & Decentralized & \\
\hline \multirow[t]{2}{*}{2} & $P S+A V+L A$ & Secondary Sulcus PC & Phakic & Traumatic cataract & - \\
\hline & & IOL Implantation & & & \\
\hline 3 & PS & $L$ & Phakic & Lens Subluxation & - \\
\hline 4 & $P S+I R$ & - & Phakic & Phakic & - \\
\hline 5 & $\mathrm{PS}+\mathrm{AV}$ & - & Phakic & Aphakia & - \\
\hline 6 & $P S+A V+I E$ & - & Pseudophakic & Pseudophakic & - \\
\hline 7 & $P S+I R$ & PPV / Scleral Fixation IOL & Phakic & Aphakia & Macular Pucker \\
\hline 8 & PS & - & Phakic & Phakic & - \\
\hline \multirow[t]{2}{*}{9} & $P S+A V+I R$ & Re-PK + Retroiridal & Phakic & Aphakia & PVR + Retinal \\
\hline & & Membrane Excision + L & & & Detachment \\
\hline 10 & PS & - & Pseudophakic & Pseudophakic & - \\
\hline 11 & PS & - & Pseudophakic & Pseudophakic & - \\
\hline 12 & PS & - & Pseudophakic & Pseudophakic & - \\
\hline \multirow[t]{2}{*}{13} & $P S+A V+I O L E$ & - & Pseudophakic & Aphakia & Suprachoroidal \\
\hline & & & & & Hemorrhage \\
\hline 14 & PS & - & Phakic & Phakic & - \\
\hline 15 & $P S+A V+I E$ & - & Phakic & Aphakia & - \\
\hline 16 & $P S+A V+L$ & $A V+$ Scleral Fixation IOL & Phakic & Traumatic cataract & - \\
\hline 17 & PS & - & Pseudophakic & Pseudophakic & - \\
\hline 18 & PS & - & Pseudophakic & Pseudophakic & - \\
\hline 19 & $\mathrm{PS}+\mathrm{AV}$ & - & Phakic & Aphakia & - \\
\hline 20 & $P S+I E+A V$ & - & Aphakia & Aphakia & - \\
\hline 21 & PS & - & Phakic & Phakic & - \\
\hline 22 & $P S+I R$ & - & Phakic & Phakic & - \\
\hline 23 & PS & - & Phakic & Phakic & - \\
\hline 24 & PS & Re-PK & Pseudophakic & Pseudophakic & - \\
\hline 25 & $P S+A V$ & - & Pseudophakic & Aphakia & - \\
\hline 26 & PS & - & Phakic & Phakic & - \\
\hline
\end{tabular}

AV: Anterior vitrectomy; IE: Iris excision; IOL E: IOL extraction; IR: Iris repositioning; L: Lensectomy; LA: Lens aspiration; PC: Posterior chamber; PPV: Pars plana vitrectomy; PS: Primary suture; PVR: Proliferative vitreoretinopathy; Re-PK: re-Penetrating keratoplasty.

ally, prolonged use of topical steroids against graft rejection has been shown to delay the wound healing process in many studies. ${ }^{[1,16,18-20]}$ In our study group, 57.7\% (15) of the patients were using topical steroids at the time of injury.

Traumatic graft dehiscence can occur at any time after $\mathrm{PK} .{ }^{[13,18]}$ In the literature, occurrences of traumatic graft rupture have been reported from 3 days to 33 years after PK. ${ }^{[1,21,22]}$ Thirtythree years is the longest reported time interval after PK, indicating a lifetime risk of traumatic dehiscence. The mean time interval between PK and TWD was 17.7 months in our study group, and in $15(57.7 \%)$ cases, trauma had occurred within the first postoperative year. Various types of injury resulting in graft dehiscence have been reported (following removal of rigid gas permeable lens, during self-installation of topical drugs, following impact by champagne cork, and bilateral graft rupture due to airbag deployment during a car accident). ${ }^{[1,16,20,23,24]}$ However, many graft ruptures occur during daily activities that are considered 'low-risk activities'. ${ }^{\text {[22] Pre- }}$ vious reports have noted that traumatic graft dehiscence was 
most often due to sports- or accident-related injuries and intentional assaults in the younger age group, ${ }^{[25,26]}$ whereas falls or self-inflicted poking were found to be more frequent in the older age group. ${ }^{[17,25,27]}$ In the current study, fall-related injuries were significantly more frequent compared to other causes in the older age group. Although Nagra et al. ${ }^{[20]}$ reported a predominance of women in their study, men were found to be at higher risk for TWD in other studies. ${ }^{[4,11,14,16-}$ $19,22,28,29]$ Williams ${ }^{[25]}$ noted that younger men are subjected to sport injuries and intentional assaults, whereas the older age group is exposed to fall-related injuries without any gender predominance. In our study group, neither gender was predominant, and no relationship was found between gender and age or trauma etiology.

There are various reports concerning the relation between primary PK indication and TWD. ${ }^{[14,19,28-31]}$ It has been noted that the most frequent indications in TWD are keratoconus, corneal scars, bullous keratopathy, herpetic keratitis, and Fuchs endothelial dystrophy. ${ }^{[4,11,14,16-20,22,23,25-32]}$ In the present study, the most frequent PK indications were consistent with the general literature: corneal scar, keratoconus, leukoma, and bullous keratopathy. As these are most common indications for $\mathrm{PK},{ }^{[33]}$ there are no definite data concerning the relationship between TWD and PK indications.

In all of our patients, the wound dehiscence was at the hostgraft junction. Likewise, other studies have also reported this region to be the most frequent site of wound separation. ${ }^{[16-20,25-32]}$ The presence of sutures does not seem to protect against wound dehiscence, and there are differing reports about the effect of suturing techniques. ${ }^{[11,18,19,20,25,27]}$ In our study group, interrupted suture was the most commonly used suturing technique, and in $16(61.7 \%)$ eyes, all or some of the sutures were in place at the time of injury. We observed no significant relationship between the extent of wound dehiscence and the suturing techniques or the presence or absence of sutures at the time of trauma. Referring to special anatomical position and the protective effects of bony structures, certain quadrants of the globe have been proposed to be more vulnerable by some researchers, while others found no quadrant predominance. ${ }^{[1,17,27]}$ In our series, the inferior quadrant was affected most frequently, followed by superior, nasal and temporal.

Kawashima et al. ${ }^{[27]}$ asserted that the extent of dehiscence is not related to etiology of the trauma. In our study, we observed no significant relationship between etiological factors and extent of dehiscence, consistent with the literature. Lam et al. ${ }^{[22]}$ apprised that grafts with larger dehiscence were more likely to fail and more likely to have loss of clarity at presentation, but we observed no significant relation between degree of dehiscence and final graft status. In the present study, damage to the crystalline lens or IOL was present in II (42.3\%) cases. In the literature, crystalline lens or IOL damage is reported to be range from $37 \%{ }^{[28]}-100 \%,{ }^{[29]}$ and is accepted as a bad prognostic sign. In a study by Tran et al. ${ }^{[31]}$ , extensive dehiscence was more frequent in cases with lens and posterior segment damage. Other studies also support this finding, and damage to crystalline lens or IOL at presentation (commonly accompanied by posterior segment injury) has been proposed as a bad prognostic sign for final visual acuity in such eyes. ${ }^{[26,27]}$ Likewise, three of our patients with posterior segment damage also had concomitant crystalline lens or IOL damage.

Surgical intervention was resuturing of the original graft in all cases, and the time interval between the causative trauma and first presentation was a mean 23.76 hours ( 1 - I 20 hours). Unless the graft is lost, resuturing of the original graft is recommended, especially in older patients, to avoid risk of explosive hemorrhage, even if the graft seems opaque. ${ }^{[17,20,23,25]}$ There is insufficient data in the literature regarding the effect of time interval from trauma to resuturing on final graft status. Topping et al. ${ }^{[16]}$ reported a case with $20 / 20$ visual acuity and clear graft who had resuturing two days after the trauma. Similarly, one of our patients who admitted three days after trauma had maintained graft clarity, whereas another who was admitted five days after the injury developed graft rejection. Nevertheless, we found no significant relation between final graft status and the time interval between injury and resuturing.

Pettinelli et al. ${ }^{[23]}$ alleged retrobulbar anesthesia to be contraindicated in cases with opened and distorted globe. We encountered no complications in the five patients underwent surgery under retrobulbar anesthesia. Rehany et al. ${ }^{[14]}$ reported a case of sulcus-fixated IOL during primary surgical repair, and they also noted that this process may pose a risk to the eye and corneal graft. None of our patients had IOL implantation during the primary surgical repair. Six of our patients required various secondary surgical procedures including PK. Especially in eyes with posterior segment damage, need for secondary surgical procedures has also been emphasized by other researchers. ${ }^{[20,31]}$

The reported percentage of grafts remaining clear after TWD varies in a wide range between $20 \%{ }^{[3]}$ and $100 \% .{ }^{[16,29]}$ Although more endothelial cell loss is expected following trauma that is severe enough to cause lens/vitreous loss, due to some physiological transformation of endothelial cells following transplantation, long-term results following resuturing are usually satisfactory. ${ }^{[3]}$ Lam et al. ${ }^{[22]}$ analyzed various factors affecting graft survival following rupture. They found no statistically significant difference when comparing sex, age, original indication for grafting, or time interval between primary surgery and trauma. However, in patients in whom sutures were removed, grafts had a more extensive dehiscence; additionally, grafts with $180^{\circ}$ or more of dehiscence were more prone to clarity loss. Likewise in our study, regarding graft clarity, we observed no statistically significant differences in age, gender, primary surgical indication, median time interval between PK 
and trauma, degree of dehiscence, affected quadrant, etiology of the trauma, median time interval between trauma and surgery, or reconstructive procedure. Among the published studies, the highest number of regrafts was reported by Tseng et al. ${ }^{[17]}$ In their series, $71.4 \%$ of grafts remained clear. Raber et al. ${ }^{[19]}$ also found that regrafting affords good prognosis. In our study group, one patient had been regrafted, and the graft remained clear during the 18-month follow-up.

Other complications apart from early damage to anterior and posterior segment structures are reported as vitreous hemorrhage, suprachoroidal hemorrhage, retinal detachment, macular pucker, glaucoma, epithelial ingrowth, hypotonia, phthisis bulbi, and need of evisceration due to complete disturbance of intraocular structures. ${ }^{[4,11,14,18,20,22,23,25,27,31 \text {, }}$ 34] Among our study population, we encountered secondary glaucoma, macular pucker, epithelial ingrowth with retinal detachment, fibrous ingrowth, and suprachoroidal hemorrhage.

Many researchers have determined severity of the trauma and posterior segment complications to be the major determinants of final visual acuity. ${ }^{[1,14,16-19,22,25,26,31]}$ In our series, when pretraumatic and final visual acuities were compared, visual acuity was improved in 5 eyes, unchanged in 7 , and worse in 14 cases. In patients whose final visual acuity was worse, the trauma was severe enough to cause $\geq 120^{\circ}$ graft dehiscence (with the exception of patients 13 and 22) and/or crystalline lens/IOL damage (patients 5, 9, 13, 15, 19 and 25); posterior segment complications were also noted (patients 9 , 13, 19, 23) (Table 2).

In conclusion, as a part of their treatment, patients should be well informed about the risk of TWD and its possible serious complications. ${ }^{[3 !]}$ In patients without major complications such as posterior segment damage, visual results and graft survival following TWD can be favorable.

Conflict of interest: None declared.

\section{REFERENCES}

1. Nordberg E. Injuries as a public health problem in sub-Saharan Africa: epidemiology and prospects for control. East Afr Med J 2000;77(12 Suppl):1-43.

2. Négrel AD, Thylefors B. The global impact of eye injuries. Ophthalmic Epidemiol 1998;5:143-69.

3. Rohrbach JM, Weidle EG, Steuhl KP, Meilinger S, Pleyer U. Traumatic wound dehiscence after penetrating keratoplasty. Acta Ophthalmol Scand 1996;74:501-5.

4. Elder MJ, Stack RR. Globe rupture following penetrating keratoplasty: how often, why, and what can we do to prevent it? Cornea 2004;23:77680 .

5. Ball JL, McLeod BK. Traumatic wound dehiscence following cataract surgery: a thing of the past? Eye (Lond) 2001;15:42-4.

6. Lambrou FH, Kozarsky A. Wound dehiscence following cataract surgery. Ophthalmic Surg 1987;18:738-40.
7. Human organ and tissue transplantation. Report by the Secretariat. Executive Board, EB112/5, 112th session, Provisional agenda item 4.3. World Health Organization. May 2003. Available: http://apps.who.int/ $\mathrm{gb} /$ archive/pdf_files/EB112/eeb1125.pdf.

8. Kang PC, Klintworth GK, Kim T, Carlson AN, Adelman R, Stinnett S, et al. Trends in the indications for penetrating keratoplasty, 1980-2001. Cornea 2005;24:801-3.

9. Aiken-O'Neill P, Mannis MJ. Summary of comeal transplant activity Eye Bank Association of America. Cornea 2002;21:1-3.

10. Cherry PM. Rupture of the globe. Arch Ophthalmol 1972;88:498-507.

11. Agrawal V, Wagh M, Krishnamachary M, Rao GN, Gupta S. Traumatic wound dehiscence after penetrating keratoplasty. Cornea 1995;14:601-3.

12. Jeganathan SV, Ghosh S, Jhanji V, Lamoureux E, Taylor HR, Vajpayee RB. Resuturing following penetrating keratoplasty: a retrospective analysis. Br J Ophthalmol 2008;92:893-5.

13. Renucci AM, Marangon FB, Culbertson WW. Wound dehiscence after penetrating keratoplasty: clinical characteristics of 51 cases treated at Bascom Palmer Eye Institute. Cornea 2006;25:524-9.

14. Rehany U, Rumelt S. Ocular trauma following penetrating keratoplasty: incidence, outcome, and postoperative recommendations. Arch Ophthalmol 1998;116:1282-6.

15. Calkins JL, Hochheimer BF, Stark WJ. Corneal wound healing: holographic stress-test analysis. Invest Ophthalmol Vis Sci 1981;21:322-34.

16. Topping TM, Stark WJ, Maumenee E, Kenyon KR. Traumatic wound dehiscence following penetrating keratoplasty. $\mathrm{Br} \mathrm{J}$ Ophthalmol 1982;66:174-8.

17. Tseng SH, Lin SC, Chen FK. Traumatic wound dehiscence after penetrating keratoplasty: clinical features and outcome in 21 cases. Cornea 1999;18:553-8.

18. Das S, Whiting M, Taylor HR. Corneal wound dehiscence after penetrating keratoplasty. Cornea 2007;26:526-9.

19. Raber IM, Arentsen JJ, Laibson PR. Traumatic wound dehiscence after penetrating keratoplasty. Arch Ophthalmol 1980;98:1407-9.

20. Nagra PK, Hammersmith KM, Rapuano CJ, Laibson PR, Cohen EJ. Wound dehiscence after penetrating keratoplasty. Cornea 2006;25:1325.

21. Farley MK, Pettit TH. Traumatic wound dehiscence after penetrating keratoplasty. Am J Ophthalmol 1987;104:44-9.

22. Lam FC, Rahman MQ, Ramaesh K. Traumatic wound dehiscence after penetrating keratoplasty-a cause for concern. Eye (Lond) 2007;21:114650.

23. Pettinelli DJ, Starr CE, Stark WJ. Late traumatic corneal wound dehiscence after penetrating keratoplasty. Arch Ophthalmol 2005;123:853-6.

24. Maharshak I, Bourla D, Grinbaum A, Weinberger D, Axer-Siegel R. Airbag-induced bilateral corneal graft dehiscence. Cornea 2005;24:110-1.

25. Williams MA, Gawley SD, Jackson AJ, Frazer DG. Traumatic graft dehiscence after penetrating keratoplasty. Ophthalmology 2008;115:276-8.

26. Steinberg J, Eddy MT, Katz T, Fricke OH, Richard G, Linke SJ. Traumatic wound dehiscence after penetrating keratoplasty: case series and literature review. Eur J Ophthalmol 2012;22:335-41.

27. Kawashima M, Kawakita T, Shimmura S, Tsubota K, Shimazaki J. Characteristics of traumatic globe rupture after keratoplasty. Ophthalmology 2009;116:2072-6.

28. Bowman RJ, Yorston D, Aitchison TC, McIntyre B, Kirkness CM. Traumatic wound rupture after penetrating keratoplasty in Africa. Br J Ophthalmol 1999;83:530-4.

29. Foroutan AR, Gheibi GH, Joshaghani M, Ahadian A, Foroutan P. Traumatic wound dehiscence and lens extrusion after penetrating keratoplas- 
ty. Cornea 2009;28:1097-9.

30. Hiratsuka Y, Sasaki S, Nakatani S, Murakami A. Traumatic wound dehiscence after penetrating keratoplasty. Jpn J Ophthalmol 2007;51:146-7.

31. Tran TH, Ellies P, Azan F, Assaraf E, Renard G. Traumatic globe rupture following penetrating keratoplasty. Graefes Arch Clin Exp Ophthalmol 2005;243:525-30.
32. Egrilmez S, Uzunel UD, Yagc1 A. Ocular trauma following penetrating keratoplasty. MN Oftalmoloji 2004;11:200-4.

33. Garg P, Krishna PV, Stratis AK, Gopinathan U. The value of corneal transplantation in reducing blindness. Eye (Lond) 2005;19:1106-14.

34. Nagra PK, Raber IM. Epithelial ingrowth in a phakic corneal transplant patient after traumatic wound dehiscence. Cornea 2003;22:184-6.

\section{KLINIKK ÇALIŞMA - ÖZET}

\section{Penetran keratoplasti sonrası travmatik yara ayrışması}

Dr. Baki Kartal, ${ }^{1}$ Dr. Baran Kandemir, ${ }^{2}$ Dr. Turan Set, ${ }^{3}$ Dr. Süleyman Kuğu, ${ }^{2}$ Dr. Sadullah Keleş, ${ }^{4}$ Dr. Erdinç Ceylan, ${ }^{1}$ Dr. Berkay Akmaz, ${ }^{2}$ Dr. Aytekin Apil, ${ }^{5}$ Dr. Yusuf Özertürk ${ }^{2}$

${ }^{1} B$ ölge Eğitim ve Araştırma Hastanesi, Göz Hastalıkları Kliniği, Erzurum

${ }^{2}$ Dr. Lütfi Kırdar Kartal Eğitim ve Araştırma Hastanesi, Göz Hastalıkları Kliniği, İstanbul

${ }^{3}$ Atatürk Üniversitesi Tıp Fakültesi, Aile Hekimliği Anabilim Dalı, Erzurum

${ }^{4}$ Atatürk Üniversitesi Tıp Fakültesi, Göz Hastalıkları Anabilim Dalı, Erzurum

${ }^{5}$ Bakırköy Sadi Konuk Eğitim ve Araştırma Hastanesi, Göz Hastalıkları Kliniği, İstanbul

AMAÇ: Penetran keratoplasti (PK) sonrası travmatik yara ayrışması için risk faktörleri, klinik özellikler ve cerrahi sonuçları değerlendirmek.

GEREÇ VE YÖNTEM: Penetran keratoplasti sonrası travmatik yara ayrışması gelişen 26 hasta travma ile ilişki faktörler, rekonstriktif cerrahi işlemler ile sonuç greft sağkalımı ve görme keskinliği açısından geriye dönük olarak değerlendirildi.

BULGULAR: Yaş ortalaması 40.7 19.6 yaş olan 26 hastanın 12'sinde (\%46. I) travmadan daha iyi gören göz etkilenmişti. En sık travma tipinin dokuz olguda (\%34.6) olmak üzere çeşitli objelerle gelişen künt travma olduğu görüldü. Ayrışma bütün olgularda greft ile alıcı bileşkesinde gelişmişti. Ayrışma genişliği ortalama $135.4^{\circ} \pm 57.6^{\circ}$ idi. Kristalin lens veya göz içi lens hasar oranı \%42.3 olarak bulundu. Cerrahi sonrası medyan takip süresi 36 aydı. On üç (\%50) hastada greft saydam kalırken, 13 hastada (\%50) greft yetmezliği/greft reddi gelişmişti. Sonuç görme keskinliği 20/200 üzerinde olan hasta sayısı $13(\% 50)$ idi.

TARTIŞMA: Travmatik yara ayrışması PK sonrası en sık birinci yılda olmak üzere herhangi bir zamanda gelişebilir. Diğer gözde görme azlığı önemli bir risk faktörü olarak gözükmektedir. Arka segmenti hasarı gibi önemli komplikasyonu olmayan hastalarda görsel sonuçlar ve greft sağkalımı olumludur. Anahtar sözcükler: Görsel prognoz; greft sağkalımı; penetran keratoplasti; travmatik yara ayrışması.

Ulus Travma Acil Cerrahi Derg 2014;20(3):181-188 doi: 10.5505/tjtes.2014.36589 